\title{
Plurality or Linearity: What is the Experience of Emerging as a School Leader in the English Context?
}

\author{
Alison Fox \\ School of Education, University of Leicester, UK
}

Copyright $\bigcirc 2016$ by authors, all rights reserved. Authors agree that this article remains permanently open access under the terms of the Creative Commons Attribution License 4.0 International License

\begin{abstract}
This study in an English context focused on the development of teachers identified as 'emergent' school leaders. It explored the aspirations and experiences of such leaders, applying a sociocultural view of identity development. Five participants from across school phases, backgrounds and ages were interviewed and generated participant learning logs over 1- 3 years. This paper focuses on the visual representations of these leaders' identity development, to reveal their multiple identities. Whilst identity development was unique, three of the leaders aspired to become senior leaders and two to become 'valued peers'. This paper poses the question as to whether schools and those supporting school leaders fully appreciate and support such plurality?
\end{abstract}

Keywords Identity Development, Leadership Development, Professional Development

\section{Introduction}

This paper reports an in-depth, longitudinal study with five school leaders in English schools, covering primary, middle and secondary school phases ${ }^{1}$. The participants were all identified by senior leaders in their schools as 'emergent' leaders. The study explored the experiences of these 'emergent leaders' to gain an understanding, not only of how the leaders reported their experiences of development, but also to reflect on the idea of 'emergence' as a leader in English schools. The 2000s, when the study was set, was the time when there began to be national concern about the throughput of school leaders. A literature review pertinent to English leadership development revealed a lack of clarity in characterising the leaders coming through to senior

1 Primary education in England caters for children from ages 4-11; middle school education, where it exists, usually caters for 9-13 year olds and secondary education either from $11-16,11-18$ or $13-18$. The actual age ranges of schools in which participating leaders taught is summarised in Table 3 . leadership. The perspective of such potential leaders was also under-represented. It was therefore thought worthwhile to spend time with those who were considered 'emergent leaders', asking them about their experiences and aspirations, to offer insights to those with responsibilities for succession planning in the profession. The study was carried out by a single researcher through developing relationships with each of the leaders and constructing with them an iterative data collection and analysis design. The study was framed using a socio-cultural perspective on the development of professionals. In particular, it conceptualises leadership development in terms of identity development.

The paper begins by setting the policy context for leadership development in English schools and the research literature forming the academic context for this study. This is followed by a presentation of the research approach and methods which generated both identity trajectory charts and narrative learning biographies. The evidence is presented; firstly, in relation to the leaders' trajectories of identity development; secondly, reflecting on patterns of development across the five leaders. Then follows a discussion about how this evidence offers insights into what 'emergence' means as a leader in English schools, including reference to useful metaphors. The paper concludes by reflecting on the challenges for those supporting school leaders in the light of this study's findings.

\subsection{The Policy Context for Leadership Development in English Schools}

Since the mid-2000s there has been a reported 'crisis' of Headteacher/Principal recruitment in the UK $(1,2,3)$, similar to that in the USA and Australasia (4). A recent survey reports no abate to this trend, in particular to early retirements (5). This retention crisis is deepened by a lack of leaders applying for top leadership posts (6).

In terms of recruitment two factors, relevant to potentially aspirant headteachers, were identified in 2010 by the 
National College ${ }^{2}$. The first was personal, relating to their negative perceptions of the job:

The report cited 43 per cent of deputies as saying that they had no desire to move up to the next rung on the career ladder. The impression of an overwhelming workload and level of responsibility are clearly acting as a deterrent to deputies, assistant heads and others with the potential for headship. Teachers and middle leaders say stress and the loss of pupil contact are also major deterrents (3)

The second factor was organisational, relating to the extended time it generally took to become a headteacher in England, which was noted to take longer than it took to achieve an equivalent level of seniority in most other professions. The report concludes that the period of standard 'apprenticeship' to headteacher in English schools lasted 20 years, comprising 15 as a classroom teacher and 5 as a Deputy (3).

In response to this critique there has been a rise in leadership development programmes offering accelerated progression - for example Fast-Track, Teach First, Future Leaders and Teaching Leaders programmes ${ }^{3}$, with marketing to University graduates to consider teaching as an attractive profession for career progression.

In England, the problem of recruitment to senior leadership positions is coupled with problems with retention in the early years of teaching (e.g. 1, 2, 6). Explanations for this wastage include reported low levels of support and high workloads beyond the newly qualified year, particularly when teachers take on additional responsibilities (7). This is a time when teachers might be considered to have become 'emergent leaders'.

Acceptance of these issues affecting the recruitment and retention of school leaders led nationally to advice and support for schools to succession plan and capacity build ( 2 , $8,9,19,45)$.

If leadership succession is not to be blighted by a leadership crisis, the question emerges as to where the next school leaders will come from. One response schools may consider is to adopt a more proactive stance towards leadership talent identification, development, succession and retention amongst existing school staff. In short, the notion of 'growing one's own leaders' has emerged $(1, \mathrm{p} 15)$.

The National College, with the support of the UK government, continues to take a lead in promoting leadership succession planning, both publishing and commissioning reports (e.g. 2, 3, 8, 9, 10). These have led to specific

2 What will be referred to as the National College or NCSL in this paper is currently the National College for Teaching and Leadership but, during the time of the study was also known as the National College for School Leadership and then National College for School Leadership of Schools and Children's Services.

3 The Fast Track programme was set up in 2002 by the non-profit making Centre for British Teachers (CfBT) Education Trust and, from 2006, was run by the National College until 2009, when it closed. Information about Teach First is available at: http://www.teachfirst.org.uk/TFHome/ and about Future Leaders at: http://www.future-leaders.org.uk/ with Teaching Leaders a programme run by the National College in conjunction with the previous two organisations. guidance being developed with and by English Local Authorities (LAs) (e.g. 11, 47). However there has been no governmental imperative for succession planning and, organisationally, schools will have responded to this climate variably.

In addition to the perceived 'crisis' in the throughput of headteachers and the change in policy context to encourage accelerated career progression, three further features, particular to the English setting, are noted:

- The wide diversity in the backgrounds of those becoming teachers (and therefore leaders) e.g. 12, 13.

- The range of ways leaders take up formal leadership positions e.g. 10, 14, 15 .

- The increasing diversity in the roles/responsibilities of school leaders e.g. 16, 17.

These cultural features can be described as having personal, organisational and policy-related facets, as summarised in Table 1.

Table 1. Cultural features relevant to English school leaders

\begin{tabular}{|c|c|}
\hline Cultural features & Category of feature \\
\hline Diversity in teacher background & Personal \\
\hline Diversity in ways leaders take up positions & $\begin{array}{c}\text { Personal; } \\
\text { Organisational }\end{array}$ \\
\hline $\begin{array}{c}\text { Diversity in leadership roles and } \\
\text { responsibilities }\end{array}$ & \begin{tabular}{c} 
Organisational \\
\hline Perceptions of throughput of headteachers
\end{tabular} \\
\hline $\begin{array}{c}\text { Personal; } \\
\text { Organisational }\end{array}$ \\
\hline Accelerated career progression & Organisational; Policy \\
\hline
\end{tabular}

At the start of the last decade the National College set out a view of UK leadership progression underpinned by a seemingly linear framework of five levels of leadership (18). Leaders were seen as developing from:

1. 'emergent leader', to

2. 'aspiring head teacher', to

3. 'new head teacher', to

4. 'long-serving head teacher' and to

5. 'consultant head teacher'.

The National College continues to offer development programmes aimed at different levels of leadership ${ }^{4}$. Schools are encouraged to identify potential programme participants and support their applications.

There appears to be an assumption that teachers taking on formal leadership roles do so as part of an expectation that they will 'emerge' into future senior leaders. This study aimed to find out whether those identified as 'emergent' hold this view and, if not, how they make sense of taking on

4 The National College now run a suite of modular leadership development courses built on a new leadership curriculum and delivered by licensed providers - "developed to support leaders at every stage of their career" (48, p3). It covers a five level model of leadership:

- Level one: leading a team

- Level two: leading across an organisation

- Level three: aspiring to lead an organisation

- Level four: leading an organisation

- Level five: leading beyond an organisation" 
school leadership roles. The research questions for the study were:

1. Who do emergent leaders want to become?

2. How do emergent leaders talk about their development?

\subsection{School Leaders' Experiences of Leadership Development}

Although the category 'emergent leader' is peculiar to the National College a search of their website in 2010 found fewer than 10 documents relating to 'emergent' leaders or 'emergent' leadership. What was present was a definition of 'emergent leadership':

[...] when a teacher is beginning to take on management and leadership responsibilities and perhaps begins to form an aspiration to become a head teacher $(19, \mathrm{p} 22)$.

This confirmed the assumption that the origins of this notion were in encouraging leaders to 'emerge' through to eventual Headship. Those leaders who might be identified as 'emergent' are recognisable in the broader leadership and management literatures, in particular being termed as 'middle leaders' or 'middle managers'. An equivalent search of the website revealed 970 references to 'middle' leaders/managers. Even the programme targeted at 'emergent leaders', as the programme's name 'Leading from the Middle ${ }^{5}$ implies, was generally referred to as being for 'middle' leaders. Bennett et al's review (20) of the role and purpose of 'middle leaders' considered related work published between 1990 and 2003 and included reference to:

- subject leaders,

- middle leaders/managers,

- heads of department and

- curriculum coordinators.

In addition to a diversity of roles, a diversity of responsibilities and expectations were also revealed, ranging from; academic, such as a subject specialist, through; managerial, such as offering staff INSET and monitoring, to; administrative, such as paperwork $(21,22,23)$. Differences in expectation might also depend on whether they are viewed as 'leader' or 'manager' (e.g. 24, 25, 26).

Bennett et al's review (20) concluded that such leaders were an identifiable but diverse cohort. What was unclear was whether they formed a category of 'emergent leaders' and, if so, what this meant in terms of the development of these leaders. Little of the published work covering such leaders offered the leaders' perspective, rather being about them (20). It was concluded that there was a need for an empirical view of how those identified as 'emergent leaders' viewed themselves and what aspirations they held.

\subsection{Identity Development as a Conceptual Framework}

A socio-cultural perspective offered a useful approach to

5 This programme was replaced in 2011 by the 'Middle Leadership Development Programme'. this study of leadership development as it accommodated both personal and cultural dimensions. This view, always socially and culturally determined, has been applied to understanding teacher learning (e.g. 27, 28, 29). It has been described as being underpinned by the metaphor of 'learning as participation' (30). Socio-culturalists see learning not as an individual activity that can be separated from interactions with others, but as associated with the relationships bound up with learning.

Wenger has developed a body of work (including 31, 32, $33,34)$ exploring and explaining the development of professionals socio-culturally.

[Learning] is the vehicle for the evolution of practices and the inclusion of newcomers, while also (and through the same process) the vehicle for development and transformation of identities (32, p13).

Identity development through social participation offered a way of thinking about 'emergence' in school settings. This perspective pays attention to the history of participation considering how prior, as well as current, social experiences inform the ongoing development of identities.

Wenger based his analysis on a view that individuals learn in relation to communities of those who are involved in similar practices ('communities of practice'). The way they develop a sense of belonging to these communities, accepting that individuals might identify with multiple communities, is explained through three modes of belonging (summarised in Table 2). Whilst it was found early on in the study that any such communities of practice were difficult to identify for these school leaders (35), modes of belonging proved useful ways of thinking about the dimensions to the leaders' identity development.

Table 2. Application of Wenger's modes of belonging

\begin{tabular}{|c|c|}
\hline The mode & Description \\
\hline Imagination & $\begin{array}{c}\text { Formation of images by individuals of what is } \\
\text { possible/desirable. } \\
\text { Related to values and beliefs. }\end{array}$ \\
\hline Alignment & $\begin{array}{c}\text { Ways in which individuals socially negotiate } \\
\text { working with others in workplaces and networks. }\end{array}$ \\
\hline Engagememt & Participation through practice. \\
\hline
\end{tabular}

Another useful aspect of Wenger's work was the way he considered identity development as made up of trajectories of participation (32). Trajectories offered a useful notion to explore the appropriateness of applying the term 'emergent' to 'emergent leaders' by looking for processes of 'emergence'. Did 'emergent leaders' emerge from identities 'as teachers' to ones 'as leaders', and then 'as early or emergent leaders' to 'as senior leaders' and ultimately 'as headteachers'?

What was difficult to understand from Wenger's work was the way the three modes related to one another; processes which explained the integration of the modes of belonging ie. The links between the three modes. As the study developed it became clear that the ideas of Sfard and Prusak (36), highlighting the central role of talk in identity development, 
could hold an answer.

Unlike Wenger, Sfard and Prusak do not see identity development as revealed in observable practices and interactions but in discourse: They 'equate identities with stories about persons' $(36, \mathrm{p} 14)$. For these authors identity is 'created', rather than 'described,' by words (29). Wenger does recognise talk but does not agree about its significance:

'We often think about our identities as self-images because we talk about ourselves and each other - and even think about ourselves and each other - in words. These words are important no doubt, but they are not the full, lived experiences of engagement in practice' $(32, \mathrm{p} 151)$

Whilst there is conceptual disagreement, the disparate views of these authors are in part related to differing methodological approaches to studying identity development. These differences needed to be resolved to allow both conceptual ideas to be integrated (37).

\section{Methodological Approach: Studying Leaders as Multiple Cases}

Wenger's approach to studying identity development was ethnographic (32), and Sfard and Prusak's based on interview-based research designs (36): Both approaches were thought valuable. These studies offered agreement that identity development is dynamic and processual and it was concluded that a longitudinal dimension to the study was required.

\section{Life history interviews $X, Y, Z$ Descriptive analysis Trial of learning log Feedback interview}

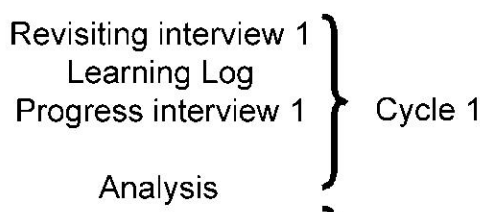
$\left.\begin{array}{c}\text { Revisiting interview 2 } \\ \text { Learning Log } \\ \text { Progress interview 2 }\end{array}\right\}$ Cycle 2 Biography production

Figure 1. Research design

Wenger's (32) ethnographic approach aimed to describe and interpret cultures through extended participant observation (38). This study's interest was in participant perspectives, rather than observers' views of their practice and required talking with emergent leaders through employing interview strategies. Individuals were expected to hold both provisional and changing perspectives, 'stories' therefore needed to be gathered in different ways and at different times. An iterative research design was developed; structured around two phases (see Figure 1). The first phase sought to reveal the 'life history' and the second the' life course' (39) of the leaders.

A case study design was adopted as 'a strategy for doing research which involves an empirical investigation of a particular contemporary phenomenon within its real life context using multiple sources of evidence' $(40, \mathrm{p} 8)$.

- The 'contemporary phenomenon' was the identity development of school leaders;

- The context, English schools;

- The 'cases', individual leaders.

As noted earlier, literature reviewed revealed a diversity both in background and role, as well as different career paths, of those who might be identified as 'emergent leaders'. By studying a number of, rather than a single, case this diversity could be recognised: Five case studies were completed. This multiple case study approach allowed a 'comparative' dimension to the research design.

\subsection{Data Collection Methods}

To gather multiple sources of evidence three main research tools were developed, employed over time and iteratively (Figure 1):

1. Interviews - to consider the perceptions of learning of participants;

2. Learning opportunity maps - to represent an individual's range of learning opportunities;

3. Learning $\operatorname{logs}$ - for participants to bring evidence of learning from beyond interview settings into interviews.

\subsubsection{Interviews}

Two types of interview strategy were developed. The first, for exploratory purposes, were life history interviews used in phase one. Popular in biographical research, these offer the potential to explore, in a holistic way, aspects of participants' lives affecting current experiences. Drawing on the 'relational' approach of academics such as Merrill and West (41), these interviews were used to create discursive settings which began both relationships building between participants and the researcher as well as exploration of participants' identity development. Three interviews were completed with each participant, with the order and venue chosen by participants:

- (Interview X) Who are you: your history? What and who have influenced you - until you started your current post? (A Curriculum Vitae was requested in advance);

- (Interview Y) Who are you - when, where and with whom do you learn? (Including mapping your network of connections) and;

- (Interview Z) Who are you when you are at school based around your current weekly diary? 
The second interview strategy fulfilled the explanatory purposes of phase two. These created opportunities to talk with the participants about their recent experiences, current thoughts and views. As part of the iterative design, themes had arisen by the end of phase one. Semi-structured interviews allowed these themes to be examined whilst retaining a flexibility to follow lines of conversation initiated by participants.

In phase one participant tended to keep accounts general, rather than referring to specific learning episodes, and accounts were limited by a lack of direct connection to learning in practice. Reflecting on the value placed by Wenger of observation it was explored with participants as to whether, in phase two, practice could be 'observed' in some way.

\subsubsection{Learning opportunity maps}

During interview Y participants generated a free-form diagrammatic representation of all those with whom they communicated professionally (see Figure 2 for an example). It was agreed this could be considered a 'map' of their learning opportunities, albeit as a snapshot.

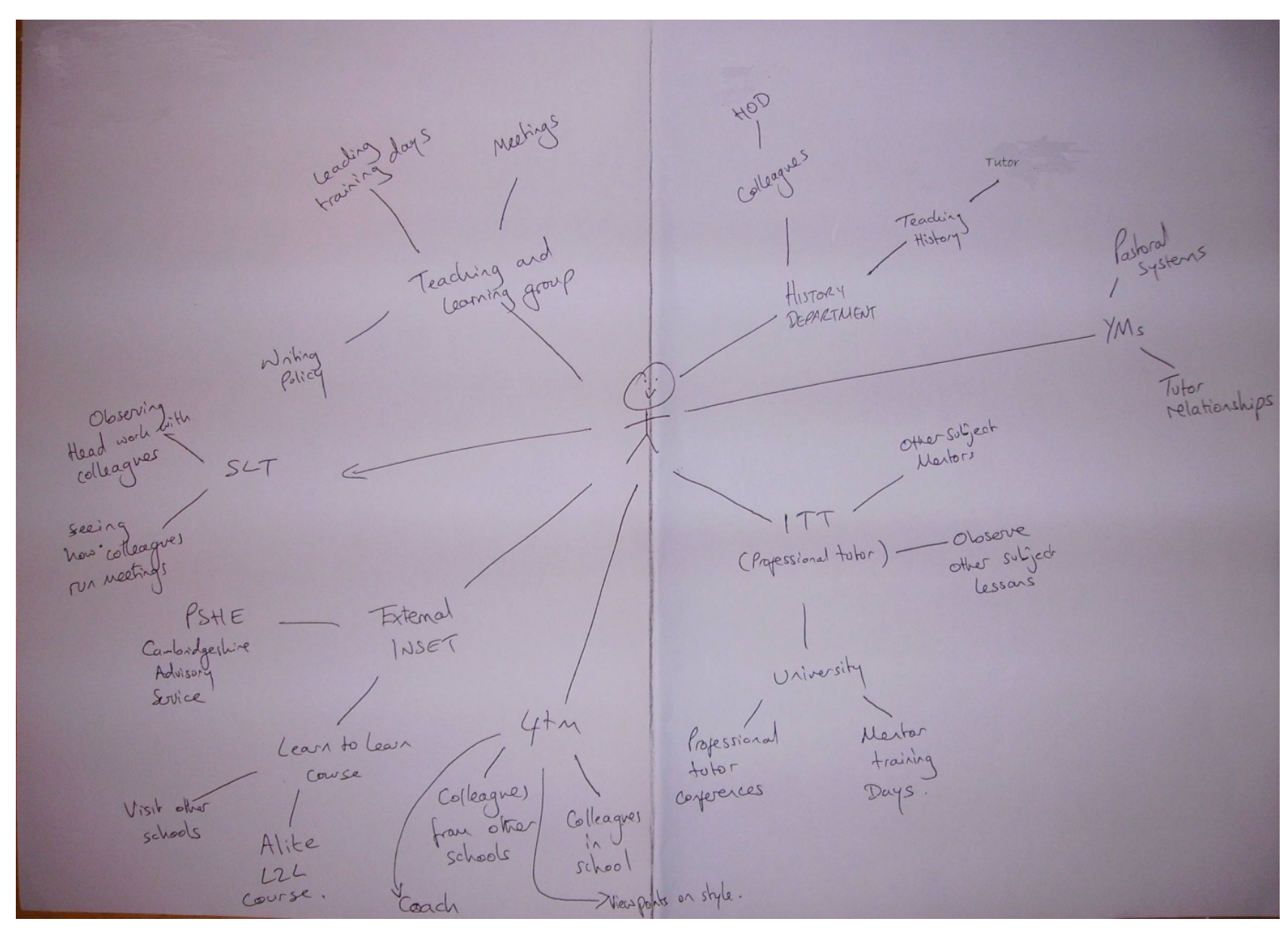

Figure 2. Learning opportunities map exemplar

\subsubsection{Learning logs}

Participants agreed to use the learning opportunities map to reflect on their learning between interviews, monitoring their learning over a month period, selecting examples which they felt best represented this learning. They brought representations of these 'learning episodes' to the final phase one interview (see Figure 1). It was suggested that participants used a camera to capture images as a form of 'self-observation'. Still, rather than audiovisual, images were thought to be less problematic both practically and ethically. Participants trialled this and were happy to identify 'learning episodes'. They did not all feel able to capture these through imagery and, going into phase two, three chose to record episodes in other ways, such as in their teaching planning diary or on sticky notes. These could be transferred onto record cards, acting as an equivalent focus to the images, for discussion.

Phase two developed a cyclical design (Figure 1). A 'revisiting' interview updated the researcher about the leader's views of their learning and, following a month learning $\log$, a 'progress' interview reflected on this log. Part of this interview asked participants to sort the episodes, and discuss the differences and similarities between them, across dimensions emerging as important during phase one. 
Table 3. Participant characteristics

\begin{tabular}{|c|c|c|c|c|c|c|c|c|}
\hline Pseudonym & Gender & $\begin{array}{c}\text { School } \\
\text { sector }\end{array}$ & $\begin{array}{c}\text { County/Local } \\
\text { Authority }\end{array}$ & First degree & Age & $\begin{array}{c}\text { Years of } \\
\text { teaching }\end{array}$ & Role at start of study & Role at end of study \\
\hline Aimee & F & Secondary & Herts & $\begin{array}{c}\text { English \& } \\
\text { Drama }\end{array}$ & 29 & 4 & Head of Drama & $\begin{array}{c}\text { Head of Expressive } \\
\text { Arts }\end{array}$ \\
\hline Amanda & F & Primary & Cambs & Music & 27 & 2 & $\begin{array}{c}\text { Music, Foreign } \\
\text { languages \& Geography } \\
\text { co-ordinator }\end{array}$ & $\begin{array}{c}\text { Assistant } \\
\text { Headteacher (second } \\
\text { school) }\end{array}$ \\
\hline Jacky & F & Primary & Cambs & $\begin{array}{c}\text { Sports } \\
\text { Science }\end{array}$ & 31 & 2 & $\begin{array}{c}\text { Numeracy \& Physical } \\
\text { Education co-ordinator }\end{array}$ & Resigned her post \\
\hline Phillip & M & Secondary & Cambs & History & 36 & 10 & Learning Director & $\begin{array}{c}\text { Assistant } \\
\text { Headteacher }\end{array}$ \\
\hline Margaret & F & Middle & Norfolk & $\begin{array}{c}\text { Social } \\
\text { Science }\end{array}$ & 51 & 6 & Humanities co-ordinator & $\begin{array}{c}\text { Humanities } \\
\text { co-ordinator }\end{array}$ \\
\hline
\end{tabular}

\subsection{The Participant Leaders}

Five leaders, covering both genders, three different English school sectors, three Local Authorities, a range of subject backgrounds, ages and years of teaching experience, participated in the study from between 13 and 36 months. All leaders were identified by their senior leaders as 'emergent leaders' and all had been invited to participate in the National College's 'Leading from the Middle' programme. Some leaders went on to participate in other leadership development courses, in particular Aimee who was part of the national Fast Track programme (see Footnote 3) and later in the study also completed the National College's Leadership Pathways programme. Jacky missed out on taking up her place on the Leading from the Middle programme through a combination of maternity leave and lack of support after her school merged with its feeder school (more details later).

The characteristics of the participants are summarised in Table 3.

\subsection{Analytic Approach: Generating Learning Biographies of School Leaders}

Identity development was presented both as charts and as narrative case study accounts which, together, produced individual 'learning biographies'. As with data collection, analysis and synthesis were also iterative. Analysis was first inductive, then deductive and finally required synthesis.
The first biographical product or case record was generated from inductive filtering of data, generating chunks of data relevant to addressing the research question 'Who does the leader want to be?' (RQ1). This data set was also considered rich enough to explore how leaders talked about their learning (RQ2). Each chunk became the dataset from which progressive 'grounded' coding generated categories and sub-categories. Apart from a prologue and epilogue the biography was presented to participants as a product largely in their own words, giving the leaders an autobiographical 'voice'. Although participants were encouraged to react to these biographies little comment was offered, other than support for its further use in analysis.

Once agreed, this case record was analysed deductively using coding developed from an adaptation of Wenger's framework of modes of belonging (Figure 3 - adapted from $\left.32, \mathrm{p} 174^{6}\right)$.

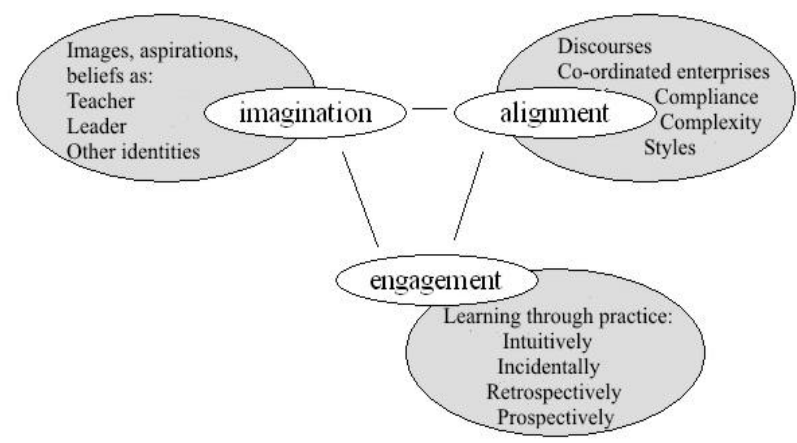

Figure 3. Analytic framework 
These categories were applied, using Atlas.ti ${ }^{\mathrm{TM}}$ software, to each case record, using mutually exclusive coding. This produced three analytic biographies for modes of 'imagination', 'alignment' and 'engagement' as tabulated data with associated commentaries.

For each leader the coded extracts were then attributed to particular identities such as learning 'as teacher', 'as leader' etc. These identities could be charted over time to give a visual representation of their presence and importance. Although visually informative, these charts are tentative and subjectively created. They are offered for wider consideration in this paper in terms of what they offer to thinking about leadership development. More illuminating still were the rich learning biographies created to describe and explain who leaders wanted to become and how they talked about their learning, but whose reporting falls beyond the remit of this paper.

\section{Results: Charting School Leaders' Identity Development}

\subsection{Identity Development as Multi-faceted}

Wenger's work talks about individuals as having multi-membership of a number of communities of practice and different trajectories towards these communities (32). Even without membership of discrete communities of practice, it was evident leaders identified with others as different groups of people at different times and as a result of holding different identities. Sfard and Prusak (36) offer identity development as the process of moving between current, 'actual', and future, 'designated', identities. The evidence from this study contributes to understanding about the closing of this 'identity gap'.

Common to all participants were the development of identities relating to their roles 'as a teacher' and 'as a leader'. This relates to the dual roles held by such leaders in English schools.

Whether leaders continued to see themselves as teachers, as well as a school leaders, depended on whether they reported synergy between these identities or not. Phillip, Jacky and Margaret reconciled their views of teaching and leading with Margaret developing the most synergy between both identities. The more she taught the more she learnt, the more she acted as a leader, the more she learnt and, by the end of the study, Margaret began to refer to herself as a learner in all contexts. Even when she spoke of what could be inferred to be leadership of ICT use in her school, Margaret did so as a teacher keen to encourage others. She had no need for a formal leadership role to act in ways others might say were 'as a leader'.

In contrast, Aimee and Amanda considered their identities as teachers and leaders as separate. Although Aimee was developing her practice as a teacher and tried to put into practice what she was advocating to others in her faculty, she saw her roles as quite different. Aimee was happy to work hard on both roles which saw her working very long hours to fulfil both. Amanda, however, started to resent the time she was expected to demonstrate that she was an excellent and model teacher, preferring to spend her time and energies on her work as a leader.

Other identities were also evident:

- as a manager, as a parent, as a TA, as a 'learner' (Margaret)

- as a historian and a potential future volunteer overseas (Phillip)

- $\quad$ as a performer (Aimee)

- as a musician and music teacher (Amanda)

- as a manager, as a sportswoman and, more recently, as a parent (Jacky)

These identities and their trajectories of development are represented in Figure 4. 


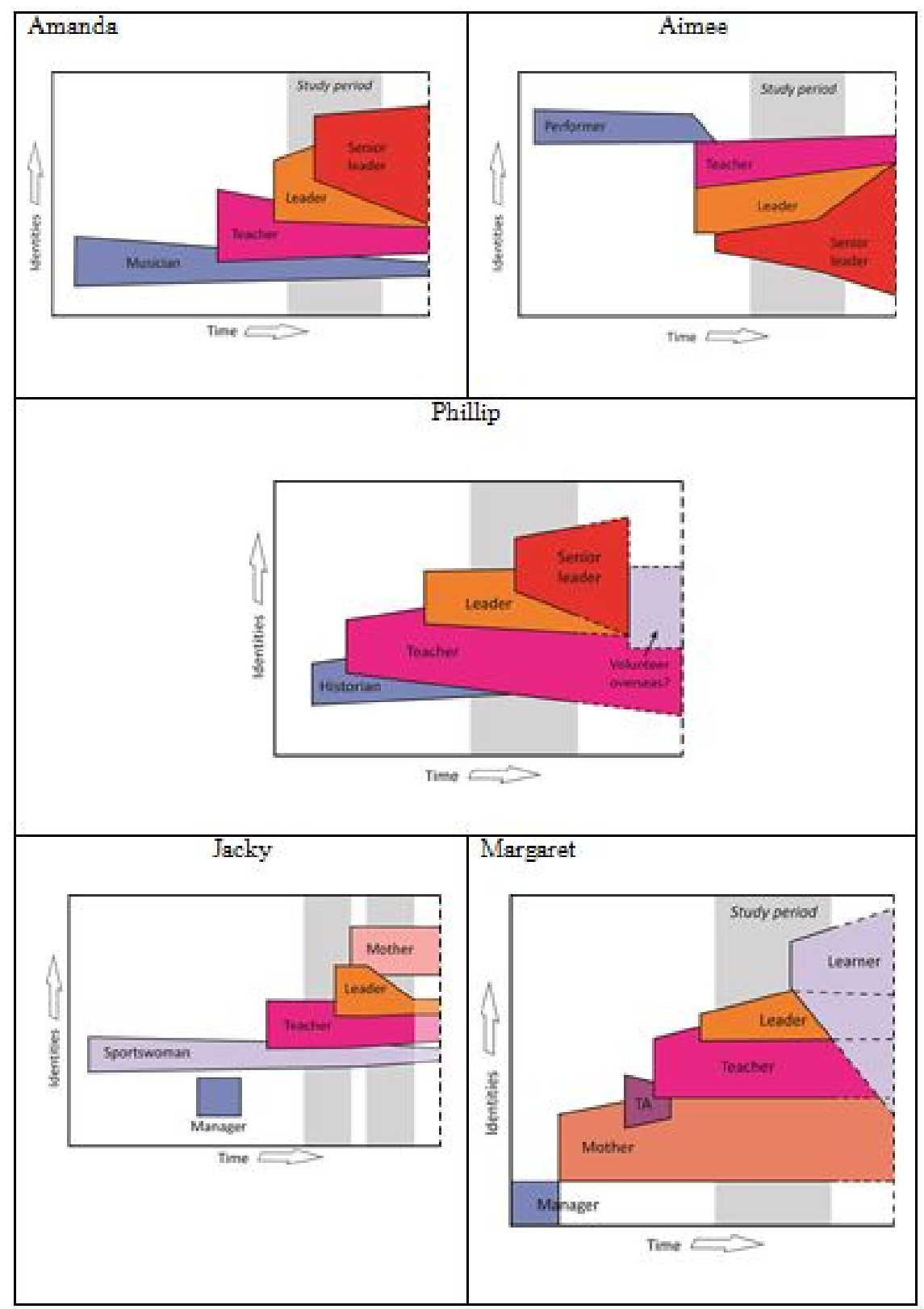

Figure 4. Representation of leader identities

These charts are qualified: In creating representations, they become overly simplistic and stylised showing a tendency to 'label' and making identities and their development appear 'unproblematic'. Figure 4 is a device for comparing the leaders' accounts of who they wanted to become (addressing RQ1). To aid its interpretation, note:

1. It is a topological representation with no scale on the axes, either of degree of 'identity development' or 'time'.

2. The period of the study is indicated. For Jacky the two blocks show the approximate position of her maternity leave during the study. All lines to the right of the period of study are, by necessity, tentative extrapolations.

3. Each identity is represented by an open-ended polygon, if it was an identity still developing by the end of the study, or a closed polygon, if it was no longer held by the leader.

4. Identities are listed top to bottom roughly as they appeared biographically, except for Jacky where synergies between sportswoman and teacher identities were evident.

5. If identities appeared to have been reconciled in any way, they are shown as overlapping. This is particularly tentatively represented.

6. It is attempted to represent whether identities were becoming more or less important by angling the sides of a polygon, although the angles are not significant.

Despite being asked about learning 'as a teacher' and 'as a leader' identities were not simply conflated with these 
terms as roles. Firstly, individuals developed very different understandings of each role and secondly, these identities could a) precede a formal role, for example Aimee's identity as a leader, or b) not relate to particular formal roles at all, for example Jacky not considering herself as a senior leader when she was ostensibly on the senior leadership team.

As Wenger's work predicted, emergent leaders reported holding more than one identity simultaneously. Some of these identities might be developing i.e. strengthening as others declined, such as Amanda's developing identity as a school leader whilst her identity as a musician declined. Sometimes individuals managed to find synergies between multiple identities and found that they could make sense of them together, such as Margaret. Where this was taking place the biographies revealed, as Wenger predicted, that this 'work of reconciliation' (32, p160) was effortful. Discussion of this is beyond the scope of this paper.

\subsection{Two Paths of Aspiration: As 'Valued Peer' or as 'Senior Leader'}

Whilst the overwhelming finding was that identity development was unique for individuals, a division was noted (see Figure 5) between those who aspired to become what were termed 'valued peers' as opposed to those who were working towards becoming 'senior leaders'.

In aspiring to become 'leaders' and then 'senior leaders' Amanda, Aimee and Phillip were seemingly on leadership 'careers' in the way the National College leadership framework outlined earlier might assume. In contrast, Jacky and Margaret's designated identities were not linked to role progression. By identifying with their peers and aspiring to work on behalf of these, promotion and role progression were not explicit aspirations. They appeared motivated to become 'valued peers/colleagues'.

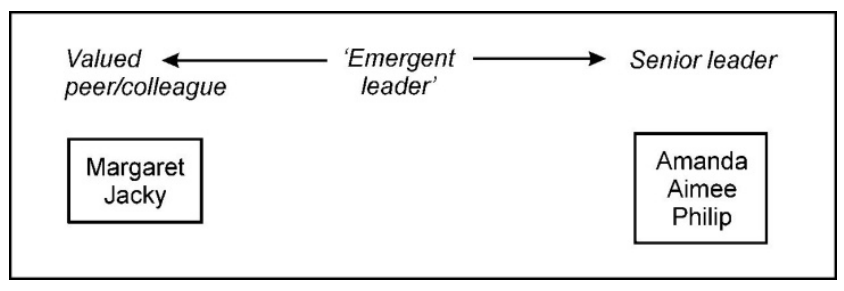

Figure 5. Typology of identity trajectories

Within each category there were differences. In terms of those aspiring to become senior leaders, different views of leadership were developed (although without space to explore these in this paper), which related particularly to their aspirations as a leader. Key aspirations cited were to: 'do something of social concern' (Phillip), of 'working hard' (Aimee) and of 'striving for efficiency' (Amanda). In Phillip and Aimee's cases these aspirations could be traced from early in their biographies to the influence of their families. Amanda explained that her desire for efficiency had only arisen once she started to work as a teacher through, in particular, her work beyond the classroom.

One finding of the study was how significant these underlying aspirations were: Integrated as they were into an individuals' identity. Leaders related these aspirations to their perceptions of the goals of the school as a place to work during the study. Schools were perceived differently by each leader emphasising different perceptions of their core purpose: as a place for teaching and learning (Phillip); as a place for achievement (Aimee) and; as organisations that operate efficiently and effectively (Amanda). These were personal views of these schools, derived by these individuals as a result of their social participation and judgments made.

There were strong similarities between the biographies of Margaret and Jacky who both aspired to be 'valued peers'. These included factors such as they both had:

- been managers in previous employment,

- been encouraged by others to consider teaching,

- needed to upgrade their qualifications in order to train as teachers,

- been in schools that merged and had to reapply for positions,

- $\quad$ started families

As a result of these experiences, they both:

- suffered from an undercurrent of under-confidence of, in particular, subject knowledge,

- addressed this under-confidence by ensuring they were up-to-date, particularly regarding subject knowledge.

- developed similar views of leadership to develop expertise to benefit others,

- drew on previous experiences where they valued the support of others, as a hockey player (Jacky) and a teaching assistant (Margaret), in developing their views of teaching and leading;

- needed to deal with the balancing of identities as a parent and as a professional (teacher/leader).

It seemed significant that these two leaders were the only ones to be parents. They offer two accounts of complex sense-making, and 'work of reconciliation' between multiple identities, including as professionals and parents. It was not possible to be clear about the role of gender on the identity development of parents as leaders as the only male in the study was not a parent. This would be worthy of further research.

As with the other leaders their accounts of identity development related to different views of their schools as a place to work. While Margaret (more like Phillip) saw her school as focused on learning, Jacky viewed her school before the merger as focused on improving pupil attainment (more like Aimee). Margaret's developing identity of herself as a learner matched how she perceived the school to operate: As a learning community. Jacky had a strong sense of herself as a team player with membership of multiple teams in the school before it merged. This view 
had clear origins in her background in team sports. This was something she felt she could apply to leading in the school before it merged but she reported a loss of any sense of team work in the reorganized school. Where there was synergy between personal aspiration and workplace perception these leaders could make sense of their three modes of belonging. They developed strong senses of belonging in relation to the schools (until circumstances changed for Jacky).

The identities Jacky and Margaret developed as leaders, however, do not easily match the expectations associated with the National College's framework as they did not report aspirations for further responsibility in school. This is slightly more difficult to conclude for Jacky. She was invited and did take on a senior leader role but her biography did not reveal that she had developed an identity 'as a senior leader', especially after the school merged and, as a combination of personal and workplace changes, she no longer felt able to enact her desired way of working.

Despite the strong similarities in the accounts of Jacky and Margaret their biographies had very different outcomes. Jacky left the profession through resigning her post and Margaret was happy to remain, despite a lack of promotion prospects.

\section{Conclusions and Implications on Emerging as a School Leader in English Schools}

Although the National College referred to "emergent leaders' the limited conceptual consideration of the term 'emergence' referred to the work of Holland (42) and Johnson (43), found in a 'Leading Practice' resource used in leadership training events run by the College (44). Holland and Johnson talk of emergence as the process of 'much coming from little' $(42, \mathrm{p} 1)$ and refer to applications of this, for example in the physical world, as with germinating seeds. These ideas were not developed by the National College in terms of leadership development other than to frame aspirations to 'emerge' into headteachers or established leaders.

If this biological metaphor for emergence is held up against the evidence of this study emergence might conjure up something dynamic: a caterpillar emerges into a butterfly (or moth); a seed into a plant. Such images imply change, direction and determination. They lead to two related questions:

1. Can the emergence of leaders be conceptualised as emerging from something?

In keeping with earlier work on teacher careers (e.g. 12, 13) it was evident from this study that individuals come to a school with unique biographies as a result of the totality of their experiences and with significance for their ongoing development. This sees leaders bringing personal and developing values, beliefs and aspirations to their current practice and offers a challenge to the biological metaphor for emergence in terms of a diversity of their origin: Emergent leaders do not begin analogous to the same type of 'caterpillar' or 'seed'.

2. Can the emergence of leaders be conceptualised as emerging to something?

Unlike a particular type of caterpillar always changing into a particular type of butterfly (or seed into plant), given the unique biographies revealed, teachers do not simply change or 'emerge' into leaders (or 'emergent leaders' into 'senior leaders'). They do not form a particular kind of leader and their leadership is framed within a unique development of their identity.

Perhaps emergence could be reformulated as leaders showing a development in capabilities towards agreed success criteria? This would require clarity as to what leaders would be expected to be capable of and how they might develop these capabilities (eg. 45). Such expectations of emergent leaders could be inferred either from theoretical models underpinning leadership (eg. 14, 25) or as articulated by a school's senior leadership: No criteria were referred to by participant leaders in this study. As part of the workplace experience of leaders in their schools reported in this paper, should such criteria be evident in a workplace/the profession, individual leaders would need to align their identities with such expectations (see Figure 3). The more explicit these expectations were in the profession, the more explicit such identity work could become.

\subsection{Conceptualising Plurality of Leaders' Identity Development}

If plurality, rather than emergence, is more strongly evident in leaders' biographies an alternative biological metaphor might be more useful: The notion of pluripotency.

Some cells in both plants and animals have the potential to become a wide range of possible future cells: These are pluripotent cells. Plant cells are particularly good examples. You can place a section of a plant leaf or stem into a suitable growing medium and, for example, new root cells and shoot cells will develop. Embryonic mammalian cells also have the potential, under different chemical conditions, to be encouraged to grow into a wide variety of adult cells. The metaphor of pluripotency holds better than emergence for visualising the development of emergent leaders in English schools, where plural outcomes of leaders' identities are evident. However, even this metaphor is not entirely applicable. Pluripotency implies known future cells or organs in terms of their role and function.

The diversity of leadership roles in English schools and a move to accelerated role progression was noted earlier. The evidence from this study leads to conclusions that it is not helpful to frame leadership development in terms of roles as they do not define the leaders inhabiting them. In part this is 
affected by the regular creation and recreation of leadership roles, such as Phillip's Learning Director and Amanda/Jacky's Teaching and Leadership Responsibility roles. More fundamentally identity development, although affected by opportunities afforded by particular roles, is not bound by them. Identities can develop prior to roles, despite roles or without even holding a formal role e.g. Margaret's leadership of ICT. Instead, development needs to be considered from a personal perspective.

Identity development is particularly affected by:

a) The roles available - determined in English schools by headteachers' decisions about school leadership and structure,

b) An individual's aspirations (not necessarily concerning roles, but likely to relate to values), and,

c) Changes in school and personal circumstances.

The ongoing and dynamic nature of identity development offers a further blow to the 'emergence' metaphor as it can never be complete. Despite loose categorisations of designated identity (see Figure 5) leadership development is concluded to be most helpfully conceptualised in terms of leaders' unique identity development. Emergence does not well represent this uniqueness.

\subsection{Challenges for Those Supporting Today's Leaders}

This study raises questions as to whether those in schools are aware of and accept such individual development and therefore plurality, in what it means to develop as a leader? Furthermore, whether schools in the English education system are set up to support such individual development?

\subsubsection{The expectations of leaders by others}

Lumby and English (46) complain that becoming a school leader requires learning a 'ritualized performance' in which 'leaders and followers are linked by a special kind of social-cultural drama' (46, p103). They imply that there are 'scripts' for how leadership is enacted in a particular school, not explicitly articulated but only observable in practice (as a 'performance'). It does seem that, in English schools, leaders experience this socialisation, 'picking up' expectations of them. This study has illustrated this process as inter-related facets to an individual's identity development.

The work of Lumby and English (46) contributes to questions raised by this study as to whether today's school leaders are aware of the plurality of leadership which exists in schools. Are senior leaders aware leaders develop in unique ways or do they assume a normative career progression? Additional data was collected in this study by approaching senior leaders to reflect on the development of participant leaders, at the invitation of the participants. Only two took up this opportunity: Those who had adopted a formal mentoring role. Both Aimee's and Amanda's (in her second school) mentors were explicit that they were supporting these leaders through increasingly more senior roles. This was what Aimee was expecting due to her Fast-Track status. No such formal relationships were in place or senior leaders forthcoming for Jacky and Margaret.

\subsubsection{Support for leadership development}

As mentioned above only two participant leaders talked about having something akin to a formal mentor-mentee relationship. There were indications of more informal mentoring relationships developing at times for the other leaders (apart from Phillip) and emergent leaders reported benefit from all such support. They particularly appreciated the opportunities for the (identity) talk these relationships afforded.

It was noted earlier that schools were being encouraged to 'talent spot' and to support leaders as they moved into more senior roles as part of 'capacity building' and 'succession planning'. There is, however, a dearth of advice on how to support leadership development and further empirical research would be beneficial.

\subsubsection{Is plurality valued?}

If each leader's development is unique and not best conceptualised as 'emergence', schools need to reflect on how plurality of development is viewed. In particular it would be interesting to find out whether identities, such as those developed by Margaret and Jacky, are as valued as those who can be concluded to aspire to senior leadership?

Illustration of the significance of this question, in the light of the data from this study, is exemplified through the trajectories of participation of Amanda and Jacky (Figure 5). Even though they started teaching in the same school at the same time and took on parallel leadership roles, they did not make the same meaning about their experiences and developed as leaders differently. This was partly explained by their different personal histories and how this led them to interpret the school and their role in it differently. It was also a result of school circumstances. Whilst neither leader liked the changes associated with their school merging. Amanda's choice was to leave the school: Jacky's to resign. These were very personal decisions.

\subsubsection{Getting to know school leaders}

What exacerbates the possibilities for differences in emergent leaders' views of leadership is the lack of explicitness surrounding the expectations (and indeed possibilities) of how to enact leadership in English schools. Schools could either explain to their staff what they believe effective leadership to be, including how this is contextualised in the practice of the school, or enter into discussions with staff about the possible models and forms of leadership they might develop. This depends whether a school advocates (or wants to advocate) a particular approach to leadership or whether it accepts (or wants to celebrate) a diversity of approaches. Being explicit about this would give individuals the chance to decide whether they can see a way to develop a sense of belonging in these 
circumstances. This paper proposes that this 'being explicit' and 'sharing meaning' involves identity talk.

Without such talk, emergent leaders' personal aspirations and the way these affect their views of leadership and their decision making remains 'hidden'. The challenge to schools therefore is 'Are they prepared to get to know their leaders and potential leaders?' This would require senior leaders taking an explicit role in involving others in identity talk. Such talk would need to be recognised by both parties as potentially mutually beneficial.

\section{REFERENCES}

[1] C.P. Rhodes, \& M. Brundrett, (2005). Leadership Succession in Schools: a cause for concern? Management in Education, Vol, 19, No. 5, 15-18.

[2] NCSL (2006). Succession Planning: Formal Advice to the Secretary of State. Nottingham: NCSL.

[3] National College for Leadership of Schools and Children's Services (NCLSCS). (2010a). Leadership succession: An overview - Securing the next generation of school leaders. Nottingham: NCLSCS.

[4] J. Macbeath. (2006) The talent enigma? International Journal of Leadership in Education, Vol. 9, No.3:183-204

[5] R. Garner (2012). Ofsted 'intimidation' risks exodus of headteachers, survey warns, article in the Independent newspaper, 4 May 2012 accessible online at: http://www.independent.co.uk/news/education/education-new s/ofsted-intimidation-risks-exodus-of-headteachers-survey-w arns-7712386.html

[6] P. Earley, D. Weindling, S. Bubb \& M. Glenn, (2009). Future leaders: the way forward? School Leadership and Management, Vol. 29, No. 3, 295-306.

[7] L. Tracey, M. Homer, N.Mitchell, A. Malderez, A..J. Hobson, A.P. Ashby, \& G. Pell. (2008). Teachers' Experiences of their Second Year in Post: Findings from Phase IV of the Becoming a Teacher project (Research Report No DCSF-RR041). Nottingham: University of Nottingham.

[8] I. Barnes, (2009). Identify and grow your own leaders: A practical guide and case studies. Nottingham: NCSL.

[9] NCLSCS. (2010b). What are we learning about...identifying talent. Nottingham: NCLSCS for Leadership of Schools and Children's Services

[10] C.P. Rhodes, M. Brundrett, \& A. Nevill, (2006). The Identification, Development, Succession and Retention of Leadership Talent: An Investigation within Contextually Different primary and secondary Schools (No. 1: Overview of Project Report). Nottingham: of Birmingham/University of Manchester/NCSL.

[11] B. Birring, (2009). Developing the workforce. Presentation as guidance for schools available from: http:/www2.kirklees.go v.uk/childrenandfamilies/learning/documents/Governors/Gov ernor/Documents-and-guidance/Staffing-Matters/Developingthe-Workforce-Governors-Conference-June-2009.pdf (last accessed 16 May 2013)
[12] C. Day, \& Q. Gu (2007). Variations in the conditions for teachers' professional learning and development: sustaining commitment and effectiveness over a career. Oxford Review of Education, Vol. 33, No.4, 423-443.

[13] E. Wilson, \& R. Deaney (2010). Changing career and changing identity: How do teacher career changers exercise agency in identity construction? Social Psychology of Education, Vol.13, 169-183.

[14] P. Gronn, (1999). The making of educational leaders. London and New York: Cassell.

[15] P. Gronn, \& K, Lacey, (2004). Positioning oneself for leadership: feelings of teachers on teaching: a survey of the teaching profession vulnerability among aspirant school principals. School Leadership and Management, Vol. 24, No.4, $405-424$

[16] I. Reid, K. Brain, \& L. Comerford-Boyes,(2004). Teachers or learning leaders?: Where have all the teachers gone? Gone to be leaders, every one. Educational Studies, Vol. 30, No.3, 251-264.

[17] Times Educational Supplement (TES) (2008). TLRs: Your questions answered. Times Educational Supplement (11 May 2008). Available from: http://www.tes.co.uk/article.aspx?storycode=2170139(last accessed 12 June 2013).

[18] NCSL (2001). Leadership Development Framework. Nottingham: NCSL.

[19] P. Collarbone, \& G. Southworth, (2009). Learning to Lead: NCSL's strategy for leadership learning. Nottingham: NCSL.

[20] N. Bennett, W. Newton, C. Wise, P.A. Woods, \& A. Economou (2003). Role and purpose of middle leaders in schools (Report prepared for the NCLSCS for School Leadership). Milton Keynes: Centre for Educational Policy and Management; The Open University for the NCLSCS for School Leadership.

[21] C. Wise (2001). The Monitoring Role of the Academic Middle Manager in Secondary Schools. Educational Management Administration and Leadership Vol. 29, No.3, 333-341.

[22] D.B. Bell. (1996). Subject specialist, coordinator, leader or manager? Paper presented at the British Educational Research Association annual conference, Lancaster University, UK, September 1996.

[23] L. Fletcher \& D.B. Bell (1999). Subject Leadership in the Primary School: Views of Subject Leaders. Paper presented at the British Educational Research Association annual conference, University of Sussex at Brighton, UK, September 1999.

[24] N. Burton \& M. Brundrett, (2005). Leading the curriculum in the primary school. London: Paul Chapman Publishing.

[25] T. Bush, (2003). Theories of educational leadership and management (3rd ed.). London: Sage Publications Ltd.

[26] A. Storey (2004). From performance management to capacity building: an escape from the cul de sac? The Curriculum Journal, Vol. 15, No.3, 207-218.

[27] K. Evans, P. Hodkinson, H. Rainbird \& L. Unwin (2006). Improving Workplace Learning. Abingdon: Routledge.

[28] H. Hodkinson \& P. Hodkinson (2005). Improving 
schoolteachers' workplace learning. Research Papers in Education, Vol. 20, No.2, 109-131.

[29] A. Sfard (2006). Participationist discourse on Mathematics learning. In J. Massz \& W. Schloeglmann (Eds.), New Mathematics Education Research and Practice. Rotterdam: Sense Publishers.

[30] A. Sfard, (1998) On two metaphors for learning and the dangers of choosing just one, Educational Researcher, Vol. 27, No.2: 4-13.

[31] J. Lave, \& E. Wenger (1991). Situated learning: legitimate peripheral participation. Cambridge: Cambridge University Press.

[32] E. Wenger (1998). Communities of practice: Learning, meaning and identity Cambridge: Cambridge University Press.

[33] E. Wenger (2010). Communities of Practice and Social Learning Systems: the Career of a Concept. In C. Blackmore (Ed.), Social Learning Systems and Communities of Practice (Vol. III, pp. 179-198). Buckingham: Springer and Open University.

[34] E. Wenger, R. McDermott, \& W.M. Snyder (2002). Cultivating communities of practice. Boston, Mass.: Harvard Business School Press.

[35] Author (2010) [details removed for the peer review process]

[36] A. Sfard, \& A. Prusak. (2005). Telling identities: In search of an analytic tool for investigating learning as a culturally shaped activity. Educational Researcher, Vol. 34, No.4, 14-22.

[37] Author (2014) [details removed for the peer review process]

[38] C. Robson (2002). Real World Research (2nd ed.). London: Blackwell.
[39] G. Biesta \& M. Tedder (2007). Learning from life and learning for life: Exploring the opportunities for biographical learning in the lives of adults, working paper 7, available from the TLRP Dspace website: http://www.tlrp.org/dspace/retrieve/2144/Working_paper7_E xeter_May+2007pdf.pdf

[40] R.K. Yin (1994). Case Study Research: Design and Methods (3rd ed.). London: Sage.

[41] B. Merrill \& L. West (2009). Using Biographical Methods in Social Research. London: Sage Publications Ltd.

[42] J. Holland (1998). Emergence: From chaos to order. Oxford: Oxford University Press.

[43] S. Johnson (2001). Emergence. Harmondsworth: Penguin.

[44] J. West-Burnham \& J. Ireson (2005). Leadership development and personal effectiveness (Report no. PB74). Nottingham: NCSL.

[45] Hay Group. (2007). Rush to the Top: Accelerating the development of leaders in schools. London: The Hay Group.

[46] J. Lumby \& F. English (2009). From simplicism to complexity in leadership identity and preparation: exploring the lineage and dark secrets. International Journal of Leadership in Education, Vol.12, No.2, 95 - 114.

[47] C.P. Rhodes \& M. Brundrett (2006). The identification, development, succession and retention of leadership talent in contextually different Primary schools: a case study located within the English West Midlands. School Leadership and Management, Vol.26, No.3, 269-287.

[48] NCTL (2013). Leadership Curriculum: Prospectus. Nottingham: NCTL.

[49] Mumford, A. (1993). How managers can develop managers. Aldershot: Gower. 